\title{
Investigating the efficacy of a proposed marine protected area for the Endangered humphead wrasse Cheilinus undulatus at a remote island group in Seychelles
}

\author{
Ryan Daly ${ }^{1,2,3, *}$, Clare A. Keating Daly ${ }^{3}$, Andrew E. Gray ${ }^{4}$, Lauren R. Peel ${ }^{1,5,6,7}$, \\ Luke Gordon $^{1,7}$, James S. E. Lea ${ }^{1,8}$, Christopher R. Clarke ${ }^{9}$, Kevin C. Weng ${ }^{10}$ \\ ${ }^{1}$ Save Our Seas Foundation - D'Arros Research Centre (SOSF-DRC), Rue Philippe Plantamour 20, 1201 Geneva, Switzerland \\ ${ }^{2}$ South African Institute for Aquatic Biodiversity (SAIAB), Private Bag 1015, Grahamstown 6140, South Africa \\ ${ }^{3}$ Oceanographic Research Institute, PO Box 10712, Marine Parade, 4056, Durban, South Africa \\ ${ }^{4}$ Joint Institute for Marine and Atmospheric Research, University of Hawaii at Manoa, Honolulu, Hawaii 96822, USA \\ ${ }^{5}$ School of Biological Sciences, The Oceans Institute and The Oceans Graduate School, The University of Western Australia, \\ Crawley, Western Australia 6009, Australia \\ ${ }^{6}$ The Australian Institute of Marine Science, Crawley, Western Australia 6009, Australia \\ ${ }^{7}$ The Manta Trust, Catemwood House, Norwood Lane, Corscombe, Dorset DT2 0NT, UK \\ ${ }^{8}$ Department of Zoology, University of Cambridge, Cambridge CB2 1TN, UK \\ ${ }^{9}$ Marine Research Facility, PO Box 10646, Jeddah, 21443, Saudi Arabia \\ ${ }^{10}$ Virginia Institute of Marine Science, College of William \& Mary, Gloucester Point, Virginia 23062-1346, USA
}

\begin{abstract}
The humphead wrasse Cheilinus undulatus is an iconic, ecologically important and Endangered fish species associated with coral reefs in the Indo-Pacific region. Due to its large size and complex life history characteristics, it is vulnerable to overfishing and has undergone substantial population declines in parts of its range. Knowledge of the species' movement ecology is currently limited to only 2 previous studies, and very little is known about populations in the western Indian Ocean. The present study aimed to use passive acoustic telemetry to investigate the importance of a remote coral reef to a population of humphead wrasse in the Republic of Seychelles, and subsequently assess the efficacy of a proposed marine protected area at this location for protection of the species. Tagged fish $(\mathrm{n}=20)$ exhibited persistent $(>500 \mathrm{~d})$ site fidelity, with low dispersal distances (mean $\pm \mathrm{SD}: 6.44 \pm 4.0 \mathrm{~km}$ ) and restricted core activity spaces (50\% Brownian bridge kernel utilization density: $0.91 \pm 0.61 \mathrm{~km}^{2}$ ). Additionally, the study site was home to a group of large (total length $97.9 \pm 20.6 \mathrm{~cm}$ ) and currently unexploited humphead wrasse that showed longterm predictable site fidelity and thus could be vulnerable to over-exploitation. The establishment of a proposed no-take marine protected area at the study site would encompass the core home range area of all tagged humphead wrasse and could effectively conserve this stronghold of Endangered fish to ensure the persistence of the species in Seychelles waters.
\end{abstract}

KEY WORDS: Humphead wrasse $\cdot$ Cheilinus undulatus $\cdot$ Home range $\cdot$ Spatial ecology $\cdot$ Coral reef Marine protected area $\cdot$ Acoustic telemetry

\section{INTRODUCTION}

The humphead wrasse Cheilinus undulatus is one of the largest fish species associated with coral reefs in the world and plays a key role in fisheries and

*Corresponding author: ryandaly.mail@gmail.com tourism in the tropical Indo-Pacific (Sadovy et al. 2003, Choat et al. 2006). Humphead wrasse may live for over $30 \mathrm{yr}$ and are protogynous hermaphrodites (Choat et al. 2006), reaching sexual maturity around 5 yr or at approximately $40-50 \mathrm{~cm}$ total length (TL),

() The authors 2020. Open Access under Creative Commons by Attribution Licence. Use, distribution and reproduction are unrestricted. Authors and original publication must be credited. 
and changing from female to male at approximately 65-80 cm TL (Sadovy et al. 2003, 2010, Liu \& Sadovy de Mitcheson 2011). The slow growth, long life span and complex reproductive strategies of the species contribute to its vulnerability to fishing pressure, and it is listed as Endangered by the IUCN Red List of Threatened Species (Sadovy et al. 2003, Russell 2004, Choat et al. 2006).

Throughout its range, from the Red Sea and western Indian Ocean into the Indo-Pacific, it has been subject to heavy fishing pressure, and evidence from the western Pacific and southeast Asia has shown that humphead wrasse populations are quickly depleted by commercial fishing practices (Sadovy et al. 2003). Such overfishing is primarily driven by the high economic value of humphead wrasse, as it is one of the most sought-after species in the live reef food fish trade (Sadovy \& Daves 2006, Wu \& Sadovy de Mitcheson 2016). Additionally, humphead wrasse may be particularly vulnerable to over-exploitation from fishing as these fish occupy shallow (up to $30 \mathrm{~m}$ depth) sleeping sites, and aggregate in highly visible spawning aggregations, where they are easily targeted (Dulvy et al. 2003, Choat et al. 2006). While populations have been decimated across much of its range, previous surveys suggest that Seychelles may be a key area for the species (Friedlander et al. 2014, Keating Daly \& Daly 2017).

In Seychelles, the economic value of humphead wrasse appears to be relatively low and there is little consumptive demand for the species. Known locally as 'aya zerar', humphead wrasse are occasionally caught as by-catch and sold in local markets. A legal live reef fish food trade once existed in the Republic (1998-1999), during which time the fishery exported nearly $20 \mathrm{t}$ of live humphead wrasse from the Farquhar Group and Aldabra Group, Seychelles, to Hong Kong (Aumeeruddy \& Robinson 2006); however, Seychelles did not renew the export permits after the trial period (Aumeeruddy \& Robinson 2006, Gillett 2010). Subsequently, humphead wrasse were listed on Appendix II of CITES in January 2005 (Wu \& Sadovy de Mitcheson 2016), and Seychelles closely followed by gazetting the ban on live fish exports in June 2005 (Aumeeruddy \& Robinson 2006). The ban stopped the trade for live humphead wrasse, but without formal protection within Seychelles waters, the humphead wrasse remains vulnerable, and dedicated conservation measures are necessary to ensure the persistence of the species in the archipelago.

Current knowledge of humphead wrasse spatial ecology is limited to a mere 2 studies worldwide in New Caledonia and Palmyra Atoll, respectively, and there is a need to improve current knowledge in order to improve existing conservation management plans (Chateau \& Wantiez 2007, Weng et al. 2015). Limitations to understanding the spatial ecology of humphead wrasse include the challenge that accessibility to large numbers of individuals is rare and limited to 'long-protected areas' (Russell 2004). In 2014, a study from Farquhar Island, one of the southernmost islands of Seychelles, found humphead wrasse in an abundance that may be the highest densities known for the species ( $6.1 \%$ of total fish biomass) (Friedlander et al. 2014). Thus, while populations are declining throughout their range, Seychelles offers a unique opportunity to study the spatial ecology of the humphead wrasse in detail (Sadovy et al. 2003, 2007).

The aim of the present study was to improve our understanding of humphead wrasse spatial ecology and evaluate if spatial management (in the form of a no-take marine protected area, MPA) may be an effective way to improve conservation measures for this vulnerable species. Our objectives were as follows: (1) acoustically tag and monitor adult humphead wrasse for $1 \mathrm{yr}$ in a monitoring array far larger than those used in prior studies; (2) calculate the area of occupancy, extent of activity space and core home range of tagged fish and compare this with fish size; and (3) investigate the overlap of a proposed MPA with the core home range and extent of activity space of tagged humphead wrasse.

Within the text, we publish detailed home range data without disclosing the geographic locations of individual animals to avoid creating new fishing effort on a healthy population of this Red-listed and CITES-controlled species. This decision was informed by a growing body of evidence in the scientific literature highlighting the risks of publishing data on endangered species and to prevent potential pre-emptive overfishing (Lindenmayer \& Scheele 2017, McDermott et al. 2019).

\section{MATERIALS AND METHODS}

\subsection{Study site}

The Economic Exclusion Zone of Seychelles spans $1374000 \mathrm{~km}^{2}$ within the western Indian Ocean, with a total land mass of $459 \mathrm{~km}^{2}$. There are 2 primary island regions in Seychelles, the Inner Islands (45 primarily granitic islands in the north including the main Island Mahé) and the Outer Islands, which in- 
cludes the Amirante Island Group (Fig. 1), where this study took place. The latter group comprises 11 lowlying sand cays with a total land area of $11.5 \mathrm{~km}^{2}$ (Stoddart 1984). Our study area included island, atoll and deep (60-70 m) channel habitats with platform

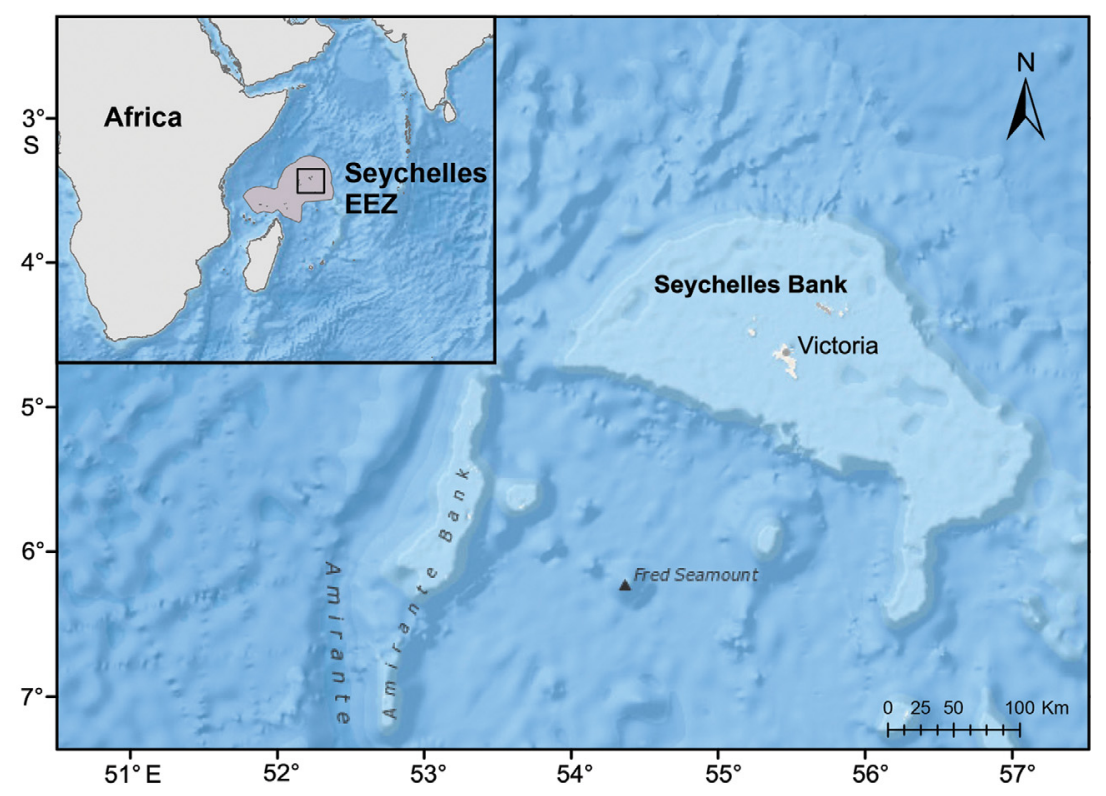

Fig. 1. Study location in a remote coral reef complex on the Amirantes Bank, Republic of Seychelles, western Indian Ocean. Inset shows the Economic Exclusion Zone (EEZ) of Seychelles (grey shading) and study region (black box). Maps created in ArcGIS 10.7 (www.esri.com/) using GEBCO_08 (version 20100927) bathymetry data reefs, lagoon, mangroves and seagrass meadows (primarily Thalassodendron ciliatum) (Stoddart et al. 1979, Stoddart 1984).

The climate in Seychelles is tropical, with sea temperatures ranging between approximately 24 and $30^{\circ} \mathrm{C}$. The northwest trade wind season occurs between December and March and is characterized by warm temperatures, high rainfall and moderate winds. The southeast trade wind season occurs between May and November and is characterized by cooler and drier conditions, consistently strong winds (up to $37 \mathrm{~km} \mathrm{~h}^{-1}$ ) and rough seas. The months of March and November are transitional periods characterized by calm seas and stable ocean conditions (Stoddart 1984).

\subsection{Fish tagging and monitoring}

Between 16 and 27 October 2017, 20 adult humphead wrasse ranging between 52 and $133 \mathrm{~cm}$ (mean $\pm \mathrm{SD}=$ $97.95 \pm 20.61 \mathrm{TL})$ were fitted with acoustic tags (Table 1). Individuals were captured by divers using a method modified from Weng et al. (2015) prior to tagging. Briefly, divers

Table 1. Tagging and detection summary data for humphead wrasse Cheilinus undulatus tagged at the study site in Seychelles in 2017. TL: total length

\begin{tabular}{|c|c|c|c|c|c|c|c|c|}
\hline Tag ID & $\begin{array}{l}\text { Release date } \\
\qquad(\mathrm{d} / \mathrm{mo})\end{array}$ & $\begin{array}{l}\mathrm{TL} \\
(\mathrm{cm})\end{array}$ & $\begin{array}{l}\text { Last detection } \\
\text { (d/mo/yr) }\end{array}$ & $\begin{array}{l}\text { Total no. of } \\
\text { detections }\end{array}$ & $\begin{array}{l}\text { No. of } \\
\text { receivers }\end{array}$ & $\begin{array}{c}\text { Total track } \\
\text { days }\end{array}$ & $\begin{array}{c}\text { Total detection } \\
\text { days }\end{array}$ & $\begin{array}{l}\text { Residency } \\
\text { index (\%) }\end{array}$ \\
\hline 13080 & $16 / 10$ & 128 & $23 / 03 / 2018$ & 7331 & 11 & 159 & 156 & 98.11 \\
\hline 13081 & $16 / 10$ & 105 & $25 / 03 / 2019$ & 9402 & 10 & 526 & 417 & 79.28 \\
\hline 13082 & $17 / 10$ & 78 & 27/03/2019 & 24744 & 11 & 527 & 507 & 96.20 \\
\hline 13083 & $18 / 10$ & 123 & $27 / 03 / 2019$ & 18017 & 7 & 526 & 511 & 97.15 \\
\hline 13084 & $18 / 10$ & 89 & 09/08/2018 & 8467 & 13 & 296 & 276 & 93.24 \\
\hline 13085 & $19 / 10$ & 92 & $26 / 03 / 2019$ & 32767 & 7 & 524 & 508 & 96.95 \\
\hline 13086 & $20 / 10$ & 94 & 07/08/2018 & 6233 & 5 & 292 & 256 & 87.67 \\
\hline 13087 & $18 / 10$ & 96 & 26/03/2019 & 27608 & 10 & 525 & 502 & 95.62 \\
\hline 13088 & $19 / 10$ & 124 & $26 / 03 / 2019$ & 28626 & 10 & 524 & 519 & 99.05 \\
\hline 13089 & $18 / 10$ & 107 & 18/03/2019 & 32154 & 14 & 517 & 398 & 76.98 \\
\hline 13090 & $21 / 10$ & 133 & $22 / 12 / 2018$ & 57934 & 8 & 428 & 424 & 99.07 \\
\hline 13091 & $17 / 10$ & 103 & 26/03/2019 & 94155 & 8 & 526 & 504 & 95.82 \\
\hline 13092 & $21 / 10$ & 81 & $27 / 03 / 2019$ & 34193 & 12 & 523 & 506 & 96.75 \\
\hline 13093 & $24 / 10$ & 91 & $26 / 03 / 2019$ & 25435 & 6 & 519 & 518 & 99.81 \\
\hline 13094 & $26 / 10$ & 66 & 27/03/2019 & 24611 & 12 & 518 & 504 & 97.30 \\
\hline 13095 & $26 / 10$ & 98 & 26/03/2019 & 27057 & 7 & 517 & 514 & 99.42 \\
\hline 13096 & $27 / 10$ & 52 & 27/03/2019 & 23760 & 10 & 517 & 507 & 98.07 \\
\hline 13097 & $27 / 10$ & 94 & $25 / 03 / 2019$ & 13441 & 10 & 515 & 512 & 99.42 \\
\hline 13098 & $26 / 10$ & 88 & $26 / 03 / 2019$ & 19150 & 8 & 517 & 496 & 95.94 \\
\hline 13099 & $27 / 10$ & 117 & 05/11/2017 & 120 & 14 & 10 & 6 & 60.00 \\
\hline Mean & & 97.95 & & 25760.25 & 9.65 & 450.30 & 427.05 & 93.09 \\
\hline $\mathrm{SD}$ & & 20.61 & & 20640.13 & 2.60 & 145.85 & 143.29 & 10.04 \\
\hline
\end{tabular}


located humphead wrasse resting locations and netted the fish in situ. A GPS point was taken at the point of capture, before the wrasse was carefully transferred to a water-filled stretcher on a research vessel. Tagging locations varied among individuals, but all were located within a $3 \mathrm{~km}^{2}$ area. Fish were kept ventral side up with their head and gills submerged and flushed with fresh sea water. Each fish was carefully measured before being surgically implanted with an acoustic tag (VEMCO-V16). The tag was sterilized in a diluted iodine bath before being inserted into the peritoneal cavity through a $2 \mathrm{~cm}$ incision that was sutured closed using 2 independent monofilament sutures. All tagged fish were given a temporary innocuous visual marker (small yellow cable tie through intra-dorsal spine membrane) and photographed to prevent recapture during the study period. Once tagged, fish were dived back down to the capture location, or suitable cave, where they could rest and recover safely. Most tagged fish $(n=13)$ were sighted post-tagging and appeared to be behaving naturally. Tagged fish were monitored by a network of 89 acoustic receivers (VR2W, VEMCO) located throughout the Amirantes Bank (Fig. 1).

\subsection{Data analysis}

We quantified the spatial ecology of humphead wrasse using metrics of detection, dispersal and activity space (Udyawer et al. 2018). Detection metrics describe the effectiveness of the monitoring array in acquiring data from the tagged animals, whereas the residency index (RI) quantifies the proportion of the track the individual was detected for $(\mathrm{RI}=$ days detected/days between first and last detection).

Dispersal and activity space metrics were calculated for each tagged individual using functions provided in the 'Animal Tracking Toolbox' extension to the package 'VTrack' (Campbell et al. 2012) in the R statistical environment (version 3.4.1; R Core Team 2017), as described by Udyawer et al. (2018). Step dispersal metrics reflected the distances travelled by individuals between subsequent detections, and were calculated using the function 'dispersalSummary'. The relationship between maximum step dispersal distance and fish size (total length) was plotted. Short-term centres of activity (COAs) for each individual were then calculated using the function 'COA' in preparation for home range analyses. The use of COAs when calculating home range ac- counted for temporally variable tag transmissions and spatial biases from fixed receiver locations (Udyawer et al. 2018). For this study, COAs were calculated every $60 \mathrm{~min}$ for each individual.

Three measures of individual home range size, i.e. total area of occupancy, core home range area and extent of activity space, were calculated using 2 commonly used methods. The first calculation was based on minimum convex polygons (MCPs), where the total area of occupancy of individuals was considered to be the full area (i.e. $100 \%$ ) encompassed by each MCP. The second method used kernel utilization distributions estimated using Brownian bridge movement models (bbKUDs), and allowed for the core home range area and extent of the activity space of individuals to be considered within their recorded range. The core home range area was defined by the area in which individuals spent more than $50 \%$ of their time, whereas the extent of an individuals' activity space was represented by the area occupied $95 \%$ of the time. All home range analyses were completed using the function 'HRSummary' from 'VTrack', and accounted for the average detection radius recorded for the Amirantes receiver array in a previous study (165 m; Lea et al. 2016).

To examine how the home range size of tagged individuals varied over the duration of the study, MCP and bbKUD areas were calculated for the entirety of each track, and also on a monthly basis. Cumulative MCP home range areas were also calculated for each individual to assess whether the length of this study was sufficient to observe the full extent of home range use for this species. Additionally, we investigated the overlap between the core home range area and extent of activity space for humphead wrasse and an MPA boundary around the study site as proposed by Lea et al. (2016).

A Spearman's rank correlation was used to examine the relationship between individual size $\left(\mathrm{TL}_{;} \mathrm{cm}\right)$ and RI, as these data were found to have non-normal residuals through a Shapiro-Wilk test. Polynomial regression was then used to examine how the core home range area and extent of activity space vary with the size of individuals. The polynomial function was chosen to allow for non-monotonic change in area vs. fish total length, since Weng et al. (2015) found that home range area peaked at intermediate fish size and then decreased. Core home range and extent of activity space areas were log-transformed prior to analysis in order to normalise the data, and TL was fitted as a quadratic variable based on previous findings by Weng et al. (2015). All tagged fish were included in these analyses, with the exception 
of fish no. 13099, which was removed due to having a short track length $(10 \mathrm{~d})$ relative to the mean track length (451 d). We compared activity space between the individuals in this Seychelles study and a prior study of Cheilinus undulatus at Palmyra Atoll (Weng et al. 2015).

\subsection{Temporal sleeping site patterns and fidelity}

In order to investigate the temporal patterns and fidelity of fish at a sleeping site, we placed a receiver directly opposite one of the primary sleeping sites within the study area. The sleeping site was a labyrinth of caves between 6 and $12 \mathrm{~m}$ depth, with typically small entrances and spacious interiors. The receiver was placed on a mooring close (within $25 \mathrm{~m}$ ) to one of the main cave entrances. Additionally, we compared these data to those from a receiver located on a western reef slope, where wrasse have been observed foraging. Data from all tagged fish at these receivers were then investigated for temporal activity patterns using Rao's spacing test (Batschelet 1981) with the software package 'Oriana' (version 4, Kovach Computing Services). Results were plotted as rose diagrams, and the level of statistical significance was determined from a table of simulated critical points with the statistical significance set to 0.05 (Russell \& Levitin 1995). Site fidelity to sleeping sites (RIsS) was investigated by calculating the RI (days detected/days between first and last detection of tagged fish) using detection data from the single receiver placed at the sleeping site.

\subsection{Restriction of geographic location data for endangered species}

To determine the risk-reward balance of publishing location data for this IUCN Endangered species, we followed a published decision algorithm (Tulloch et al. 2018) (Table S1 in the Supplement at www.intres.com/articles/suppl/n042p007_supp.pdf). For humphead wrasse, the result of following the decision tree was as follows: Based upon this decision tree, the recommended publication format is either 'Restrict data: mask species IDs and not locations, or publish high-res habitat maps' or 'Restrict data: mask species IDs and locations'. Since this is a singlespecies research project, masking the species would negate any value in publication of results. Therefore, we felt that the most appropriate format was to mask the geographic locations.

\section{RESULTS}

\subsection{Tagging}

The 20 humphead wrasse fitted with acoustic tags were monitored for between 516 and $527 \mathrm{~d}$ (duration from tagging to last receiver download) by 89 acoustic receivers deployed throughout the Amirantes Bank, Republic of Seychelles. During this period, an average of $25760 \pm 20640$ (mean $\pm \mathrm{SD}$ ) detections were recorded per fish on between 5 and 14 unique receivers (25 [28.1\%] of total; Fig. 2). Tagged fish were detected for an average of $427 \pm 143 \mathrm{~d}$ and exhibited residency indices of between 60.0 and $99.8 \%$ (93 \pm $10 \%$; Table 1). Given the relatively short track length (10 d) of fish 13099, we excluded this individual from subsequent analyses and hereafter refer to the other 19 fish as 'all' tagged individuals.

\subsection{Dispersal distance}

The greatest maximum step dispersal distance recorded for all tagged fish was $16.16 \mathrm{~km}$ (ID 13095), whereas the mean maximum step dispersal distance for all fish was $6.44 \pm 4.0 \mathrm{~km}$ (mean $\pm \mathrm{SD}_{\text {; Fig. 3, }}$ Table 2). All tagged fish larger than $100 \mathrm{~cm}$ TL exhibited a maximum step dispersal distance of less than $8 \mathrm{~km}$, with the largest tagged fish (133 cm TL) exhibiting the smallest maximum step dispersal distance (2.1 km Fig. 3). The mean step dispersal distances exhibited by tagged fish was only $0.072 \pm$ $0.37 \mathrm{~km}$, reflecting the fact that they undertook relatively restricted movements during the monitoring period (Figs. $2 \& 3$, Table 2).

\subsection{Residency}

Fish size did not appear to be an important predictor of RI (Spearman rank correlation, $r_{\mathrm{s}}=-0.12, \mathrm{p}=$ 0.94), with all fish ranging from 52 to $124 \mathrm{~cm}$ TL exhibiting residency indices of above $95 \%$ for the length of the study (Fig. 4).

\subsection{Home range}

The total area of occupancy, extent of activity space and core home range area for tagged fishes were considered collectively at the study site (Fig. 5). Individual fish activity spaces fell into 4 spatial groups: a northern group (13082, 13086, 13090, 13091, 13092, 13094), a 


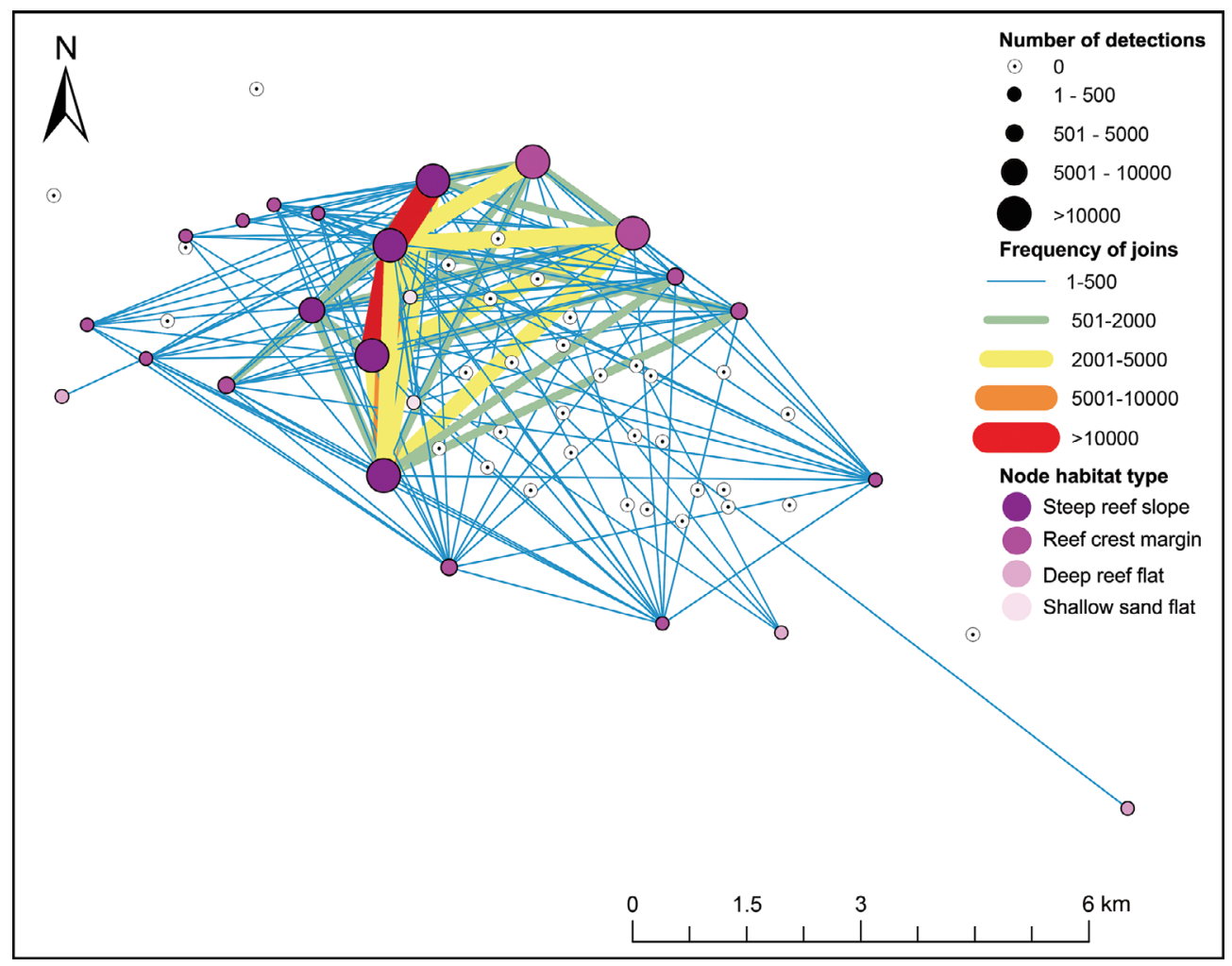

Fig. 2. Network plot displaying total receiver detections (nodes) and connectivity between receivers (joins between nodes) for 20 humphead wrasse Cheilinus undulatus tagged at a remote location in Seychelles for the duration of this study (527 d)

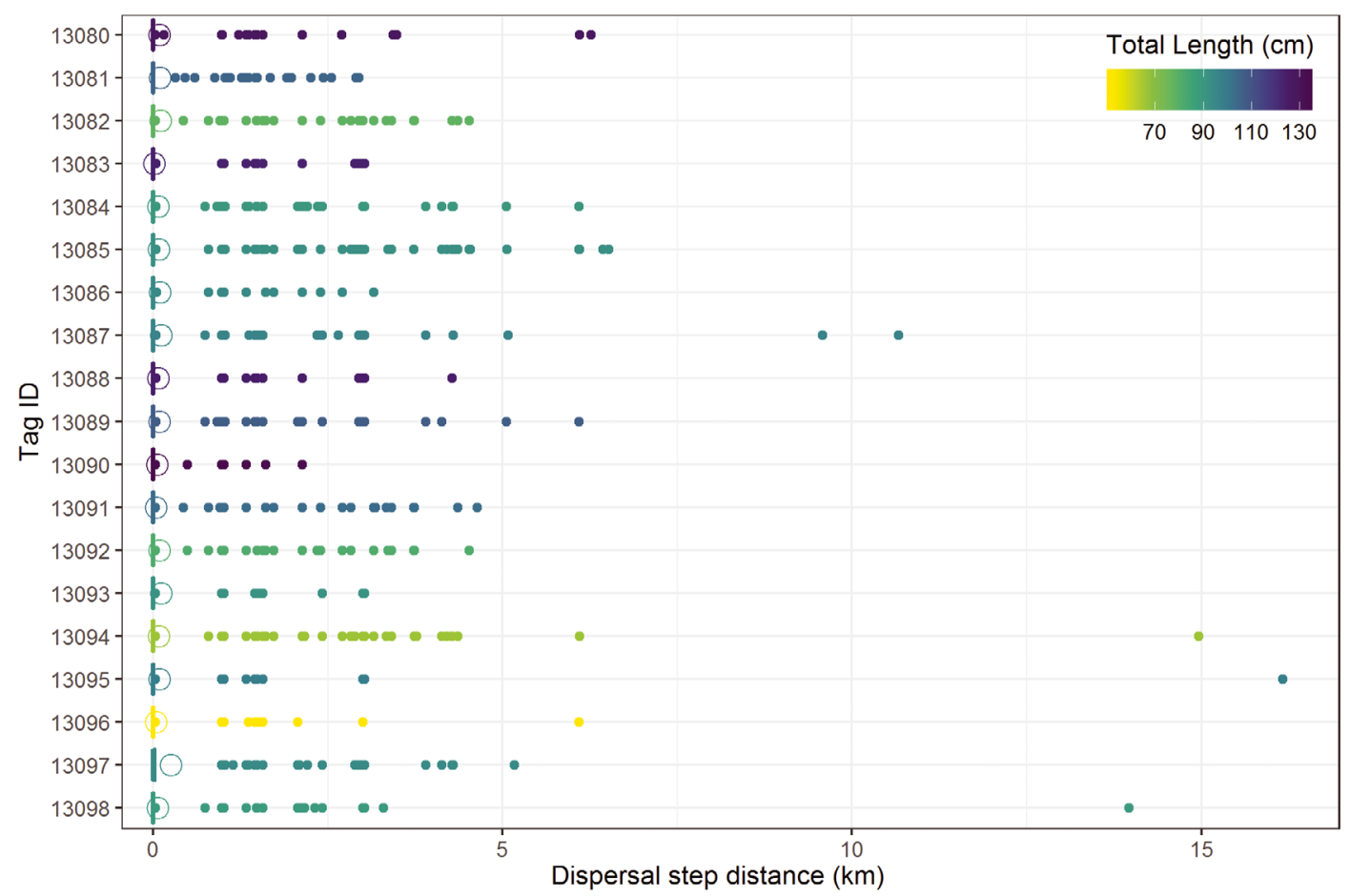

Fig. 3. Range, mean and maximum dispersal step distances $(\mathrm{km})$ of 20 humphead wrasse Cheilinus undulatus of various sizes (total length; see figure key) acoustically tagged at a remote location in Seychelles as calculated from raw detection data. Open circles represent mean dispersal step distance, and filled dots represent outliers ( $>1.5 \times$ interquartile range). Note that Tag 13099 had very little detection data and a short period of monitoring relative to all other tags ( $0.5 \%$ of average number of detections) 
Table 2. Movement and home range metrics for humphead wrasse Cheilinus undulatus acoustically tagged (Tag ID) at the study site in Seychelles in 2017. Mean and maximum (max.) step dispersal metrics represent distance travelled between subsequent detections. Core home range (50\% contour) and extent of activity space (95\% contour) calculated using Brownian bridge kernel utilization density (bbKUD). Minimum convex polygons (MCPs) were used to calculate total area of occupancy $(100 \% \mathrm{MCP})$ over space $\left(\mathrm{km}^{2}\right)$ and time (months). TL: total length

\begin{tabular}{|c|c|c|c|c|c|c|c|}
\hline \multirow{2}{*}{$\begin{array}{l}\text { Tag } \\
\text { ID }\end{array}$} & \multirow{2}{*}{$\begin{array}{c}\mathrm{TL} \\
(\mathrm{cm})\end{array}$} & \multicolumn{2}{|c|}{ —Dispersal $(\mathrm{km}) ـ$} & \multicolumn{2}{|c|}{ bbKUD $\left(\mathrm{km}^{2}\right)$} & \multicolumn{2}{|c|}{ Occupancy } \\
\hline & & Mean \pm SD & Max & $\begin{array}{l}\text { Core } \\
\text { range }\end{array}$ & $\begin{array}{c}\text { Activity } \\
\text { space }\end{array}$ & $\begin{array}{l}\text { Area } \\
\left(\mathrm{km}^{2}\right)\end{array}$ & $\begin{array}{l}\text { Time } \\
\text { (mo) }\end{array}$ \\
\hline 13080 & 128 & $0.093 \pm 0.367$ & 6.268 & 0.764 & 4.046 & 19.700 & 6 \\
\hline 13081 & 105 & $0.101 \pm 0.378$ & 2.947 & 0.772 & 9.275 & 4.939 & 14 \\
\hline 13082 & 78 & $0.102 \pm 0.444$ & 4.526 & 1.440 & 7.567 & 21.905 & 13 \\
\hline 13083 & 123 & $0.02 \pm 0.162$ & 3.030 & 0.336 & 3.732 & 14.279 & 3 \\
\hline 13084 & 89 & $0.073 \pm 0.376$ & 6.095 & 0.513 & 4.606 & 14.279 & 5 \\
\hline 13085 & 92 & $0.082 \pm 0.427$ & 6.517 & 1.975 & 22.289 & 27.188 & 14 \\
\hline 13086 & 94 & $0.1 \pm 0.399$ & 3.160 & 0.797 & 4.178 & 3.807 & 13 \\
\hline 13087 & 96 & $0.116 \pm 0.541$ & 10.671 & 0.904 & 6.506 & 43.502 & 11 \\
\hline 13088 & 124 & $0.07 \pm 0.345$ & 4.277 & 0.737 & 4.426 & 6.473 & 2 \\
\hline 13089 & 107 & $0.093 \pm 0.414$ & 6.095 & 0.572 & 4.030 & 14.279 & 18 \\
\hline 13090 & 133 & $0.053 \pm 0.256$ & 2.132 & 0.291 & 2.905 & 2.069 & 5 \\
\hline 13091 & 103 & $0.043 \pm 0.316$ & 4.636 & 0.946 & 6.007 & 8.077 & 1 \\
\hline 13092 & 81 & $0.086 \pm 0.379$ & 4.526 & 1.321 & 11.311 & 25.824 & 13 \\
\hline 13093 & 91 & $0.114 \pm 0.456$ & 3.030 & 0.624 & 4.055 & 3.148 & 11 \\
\hline 13094 & 66 & $0.085 \pm 0.402$ & 14.960 & 0.461 & 6.637 & 25.553 & 13 \\
\hline 13095 & 98 & $0.088 \pm 0.405$ & 16.164 & 0.802 & 4.332 & 6.473 & 17 \\
\hline 13096 & 52 & $0.04 \pm 0.262$ & 6.095 & 0.343 & 2.124 & 8.846 & 18 \\
\hline 13097 & 94 & $0.253 \pm 0.662$ & 5.170 & 1.479 & 6.718 & 14.683 & 11 \\
\hline 13098 & 88 & $0.064 \pm 0.305$ & 13.968 & 0.343 & 3.501 & 7.876 & 14 \\
\hline Mean & & 0.088 & 6.540 & 0.812 & 6.223 & 14.363 & 10.632 \\
\hline $\mathrm{SD}$ & & 0.048 & 4.240 & 0.455 & 4.503 & 10.722 & 5.356 \\
\hline
\end{tabular}

western group $(13083,13084,13088$, 13089, 13093, 13095, 13097, 13098), a west-south group $(13080,13085,13087$, 13096) and 1 individual in the western periphery (13081) that was tagged at that location.

A cumulative activity space plot showed that all tagged fish reached at least $75 \%$ of their total area of occupancy $(100 \% \mathrm{MCP})$ between 5 and $10 \mathrm{mo}$, with the majority of fish $(75 \%)$ reaching their total area of occupancy asymptote within 13 mo (Fig. 6, Table 2).

Total areas of occupancy for all tagged fish ranged between 3.1 and $43.5 \mathrm{~km}^{2}$, with a mean of $14.36 \pm$ $10.7 \mathrm{~km}^{2}$ (Fig. 5, Table 2). Core home range areas ranged between 0.29 and $1.98 \mathrm{~km}^{2}$, with a mean value of $0.81 \pm$ $0.46 \mathrm{~km}^{2}$, whereas the extent of activity space for individuals ranged from 2.12 to $22.29 \mathrm{~km}^{2}$, with an average area of $6.22 \pm 4.5 \mathrm{~km}^{2}$ (Fig. 5, Table 2). The extent of activity space did not appear to vary with individual size (Fig. 7a, polynomial regression, $F_{2,16}=3.28$, $\mathrm{p}=0.06$ ), whereas a slight significant relationship was observed between size and the area of the core activity space of individuals (polynomial regression, $F_{2,16}=3.80, \mathrm{p}=0.04$; Fig. $7 \mathrm{~b}$ ).

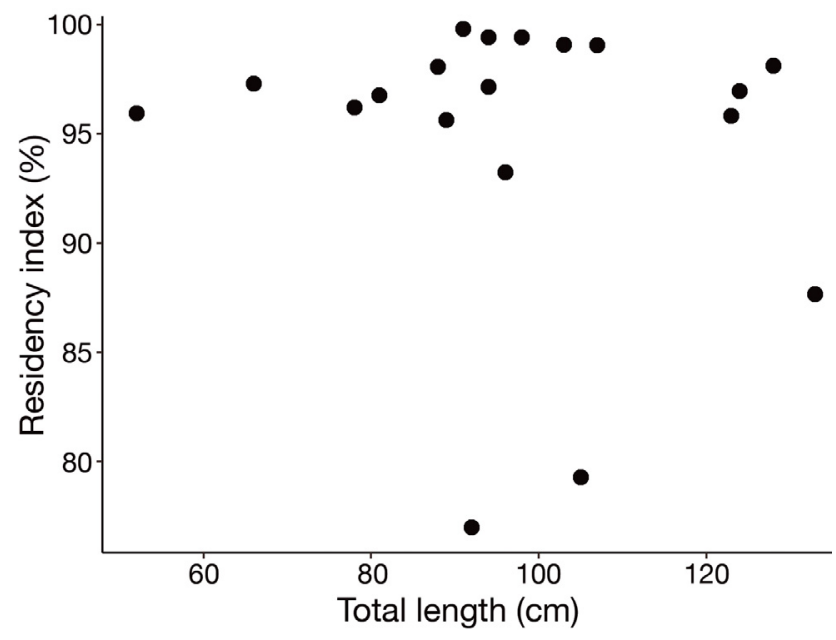

Fig. 4. Humphead wrasse Cheilinus undulatus size (total length ${ }_{i} \mathrm{~cm}$ ) vs. residency index (RI) for all individuals acoustically tagged at a remote location in Seychelles, excluding fish no. 13099

\subsection{Home range overlap with MPA}

The home ranges of all tagged fish were overlaid to present a combined plot, which was then overlaid with a previously proposed no-take MPA boundary (Fig. 8). All of the core home range areas of all tagged fish occurred inside of the proposed MPA boundary. Additionally, the extent of the activity space and total area of occupancy of 18 out of the 19 tagged fish occurred within the proposed MPA boundary (Lea et al. 2016).

\subsection{Temporal sleeping site patterns and fidelity}

The detections from a receiver placed outside the primary sleeping site for the wrasse tagged in this study exhibited significantly more detections during crepuscular and evening periods (17:00-07:00 h), with 


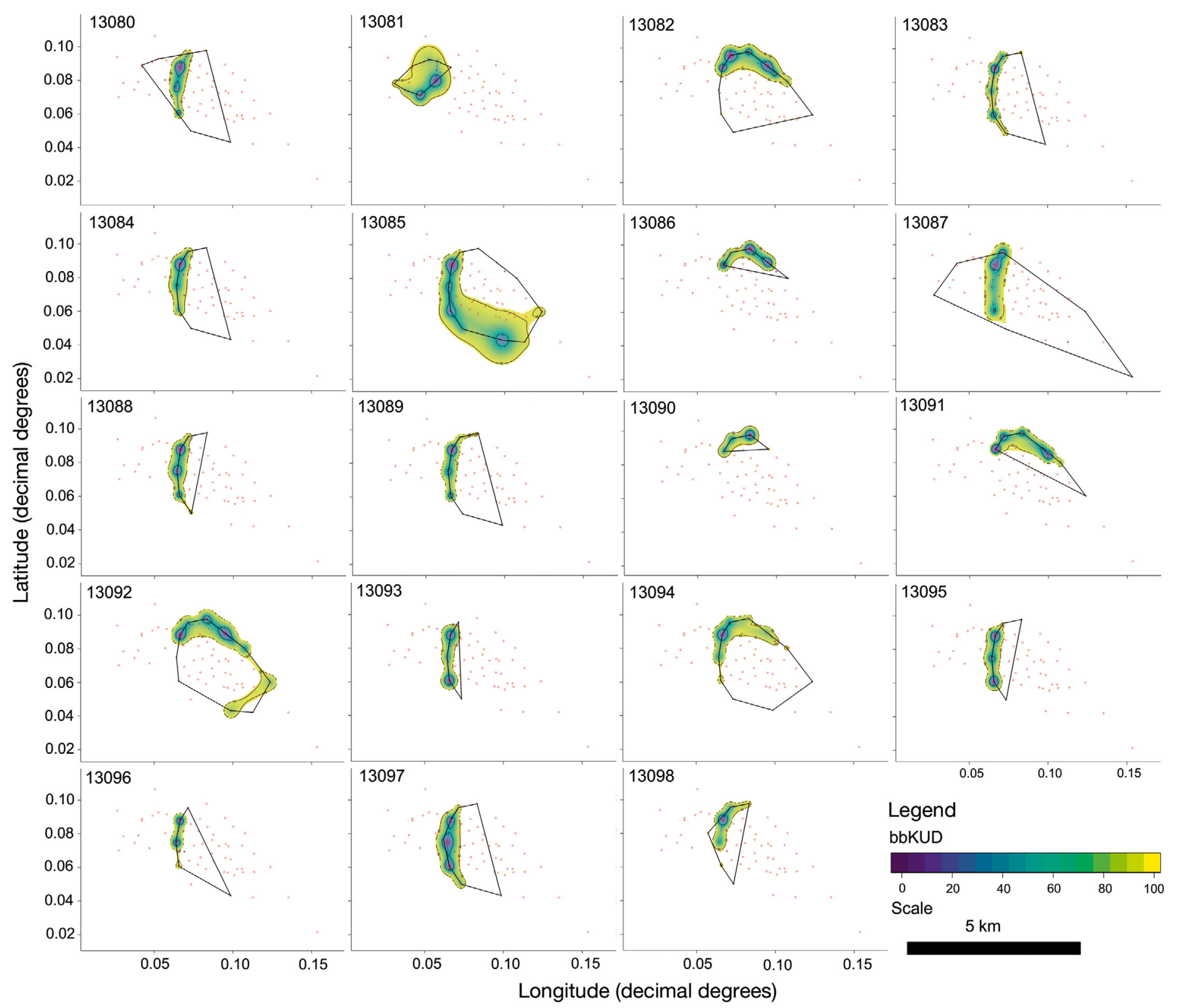

Fig. 5. Home range areas of 19 acoustically tagged humphead wrasse Cheilinus undulatus at a remote location in Seychelles. Minimum convex polygons (solid black lines) represent total area of occupancy. Brownian bridge kernel utilization densities (bbKUDs; range 0 to $100 \%$ ) represent the core home range area (50\% bbKUD) and the extent of activity space (95\% bbKUD) of tagged fish at the study site. Red dots represent acoustic receiver locations. Fish ID numbers are in the top left of each panel. Pseudo-latitude and pseudo-longitude values are displayed in decimal degrees. Actual location and geographic features are omitted due to the sensitive nature of the data

a peak in detections coinciding with dusk (18:00-19:00 $\mathrm{h}_{\mathrm{i}}$ Rao's spacing test, $\mathrm{p}<0.01$; Fig. 9a). These data supported observations made during the study period, when wrasse were observed congregating outside of the sleeping site at dusk before entering the sleeping caves before dark. Conversely, the detections from a receiver located on a western reef slope at a site where fish were observed foraging, recorded significantly more detections during the day between 07:00 and 18:00 h (Rao's spacing test, $\mathrm{p}<0.01$; Fig. 9b). The majority $(55 \%)$ of the tagged fish exhibited persistent site fidelity to the sleeping site $\left(\mathrm{RI}_{\mathrm{SS}}>0.5\right)$ throughout the study period. A proportion of tagged fish ( $45 \%$ ), however, appeared to undertake only sporadic visits to the primary sleeping site $\left(\mathrm{RI}_{\mathrm{SS}}<0.5\right)$ and most likely used alternative sleeping sites nearby. 


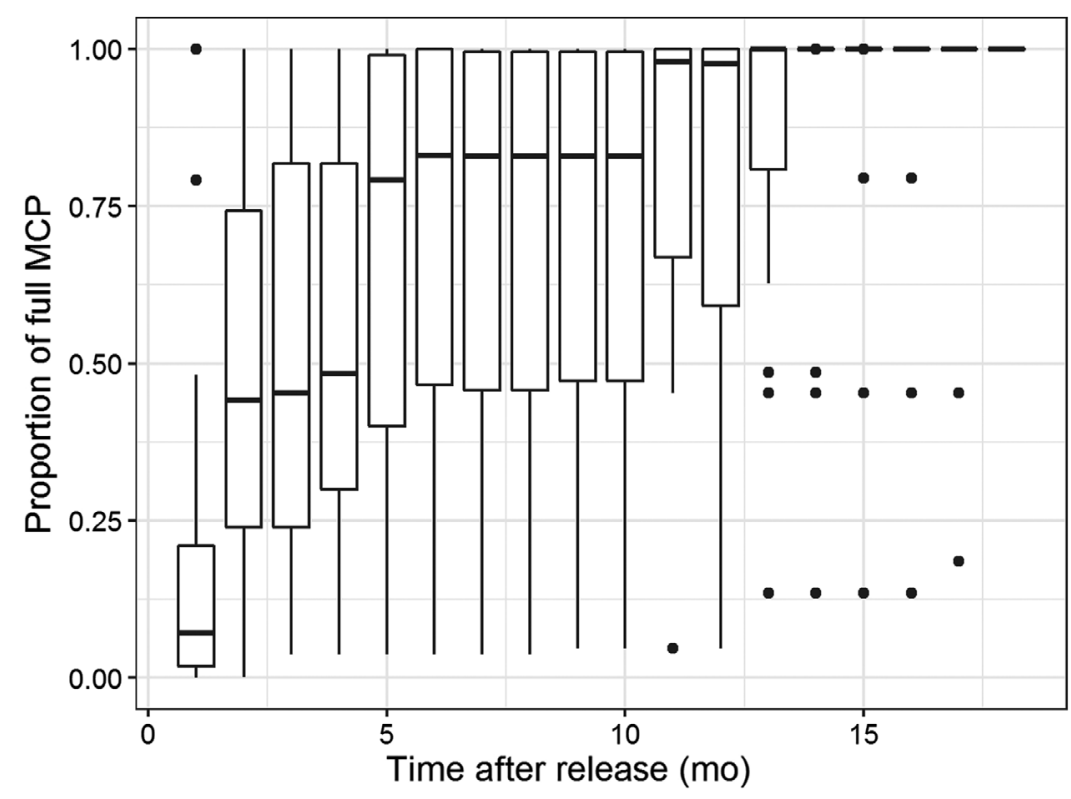

Fig. 6. Cumulative activity space plot showing the proportion of the total area of occupancy $\left(100 \%\right.$ minimum convex polygon [MCP], $\left.\mathrm{km}^{2}\right)$ used over time after release (months) for tagged fish. The proportion is the cumulative MCP at that time divided by the maximum MCP for that individual. For each time, the boxplot shows the distribution of proportions across the 19 tagged individuals (tag 13099 excluded due to limited data). Centre line of boxes represents the median, upper and lower hinges of boxes represent first and third quartiles, whiskers extend from hinges to the highest value that is within $1.5 \times$ the interquartile range, and outliers outside of this range are represented by dots. After $5 \mathrm{mo}$, the tagged individuals' median cumulative MCP area was $75 \%$ of their maximum MCP area. After 13 mo, the tagged individuals' median cumulative MCP area was equal to their maximum area
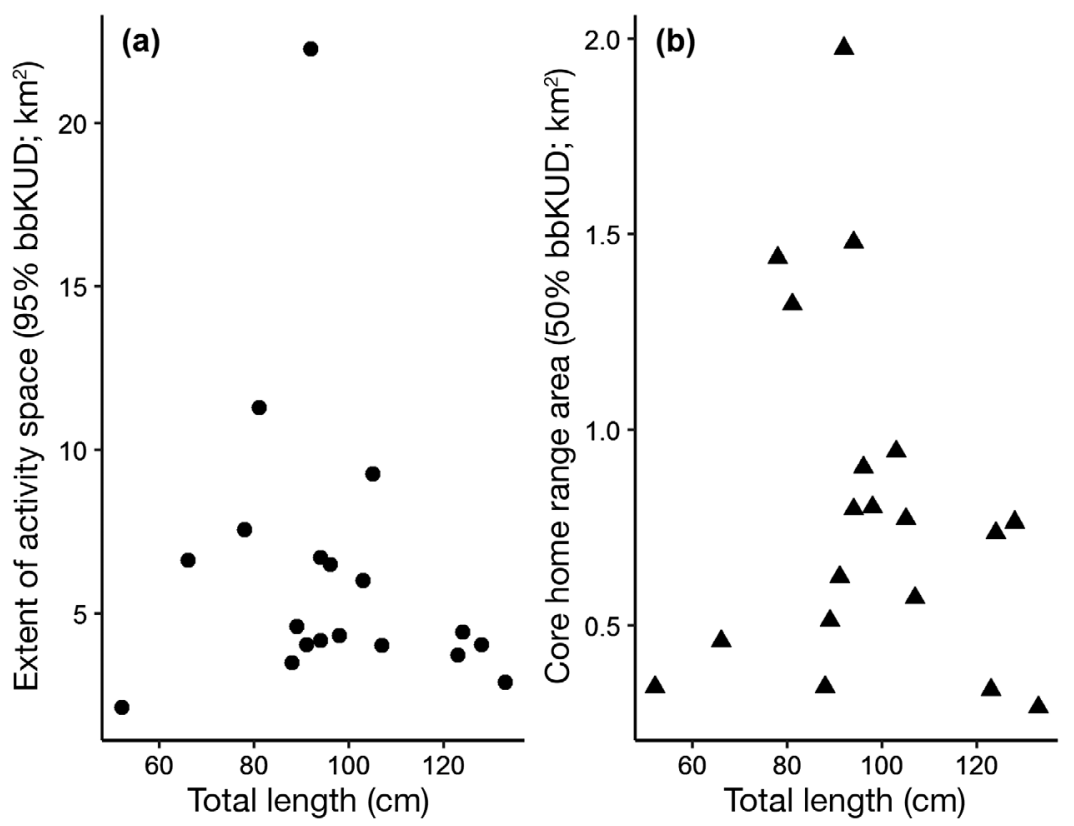

Fig. 7. (a) Extent of activity space (95\% Brownian bridge kernel utilization density, bbKUD) and (b) core home range area (50\% bbKUD) vs. total length for 19 humphead wrasse acoustically tagged at a remote location in Seychelles. Note that fish 13099 is not included due to comparative lack of data

\subsection{Habitat preference}

The greatest number of detections $(83 \%)$ were recorded on only 6 receivers at the study site (see receivers with $>5000$ detections, Fig. 2). Each of these 6 receivers was located on a reef drop-off near a relatively deep $(70 \mathrm{~m})$ channel between 2 islands. Shared features between all 6 receiver locations included the proximity $(<50 \mathrm{~m})$ of a shallow (5 $\mathrm{m}$ deep) reef crest dominated by hard coral communities (primarily Acropora, Pocillopora and Porites colonies), nearby seagrass beds (Thallasodendron spp.) and an adjacent drop off (5$35 \mathrm{~m}$ ). This was in contrast to other habitat types, such as an adjoining lagoon and shallow, low-profile reef, where few detections were recorded. The proximity and availability of refuges (caves or holes in the reef) and sleeping sites (caves) appear to be the most important features of preferred humphead wrasse habitat, based on in-field observations of the habitat surrounding the receivers that recorded the greatest number of tag detections.

\section{DISCUSSION}

Extensive exploratory diving and findings of previous reef fish surveys completed at the study site in Seychelles (Daly et al. 2018) indicated that the area was home to a relatively undisturbed population of humphead wrasse, consisting primarily of large $(>100 \mathrm{~cm})$, mature and old $(16+\mathrm{yr})$ individuals (Choat et al. 2006). Passive acoustic telemetry was used to monitor the movement patterns and site fidelity of 20 individuals, revealing persistent site fidelity (>500 d) to, and restricted movements away from, the study area. Collectively, these findings have important implications for the conservation of this Endangered species in the western Indian Ocean. 


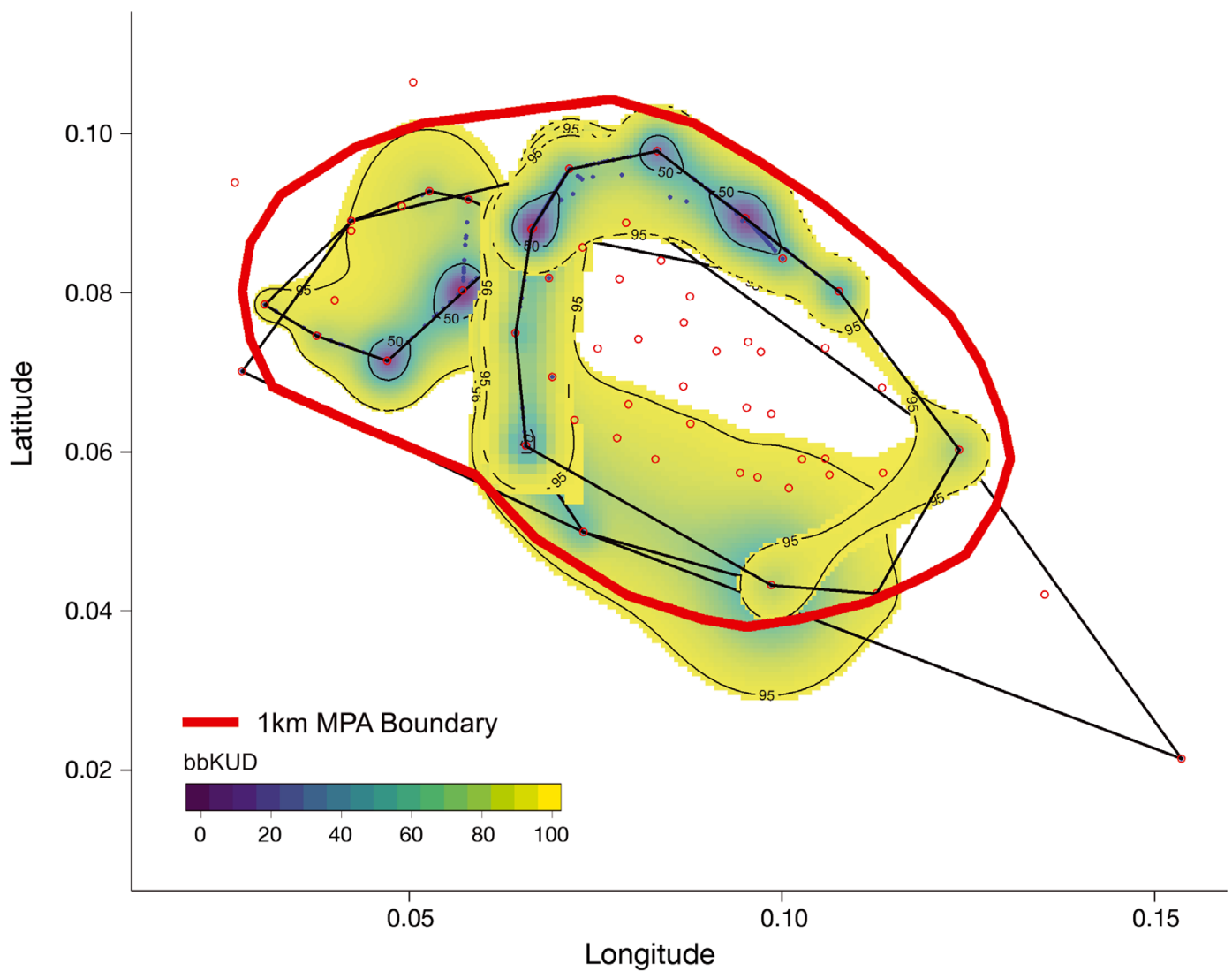

Fig. 8. Overlaid space use of 19 acoustically tagged humphead wrasse represented by minimum convex polygons (solid black lines) and Brownian bridge kernel utilization density (bbKUD) plots. Red line represents proposed no-take marine protected area (MPA) boundary. Red dots represent acoustic receiver locations. Pseudo-latitude and pseudo-longitude values are displayed in decimal degrees. Actual location and geographic features omitted due to the sensitive nature of the data

a

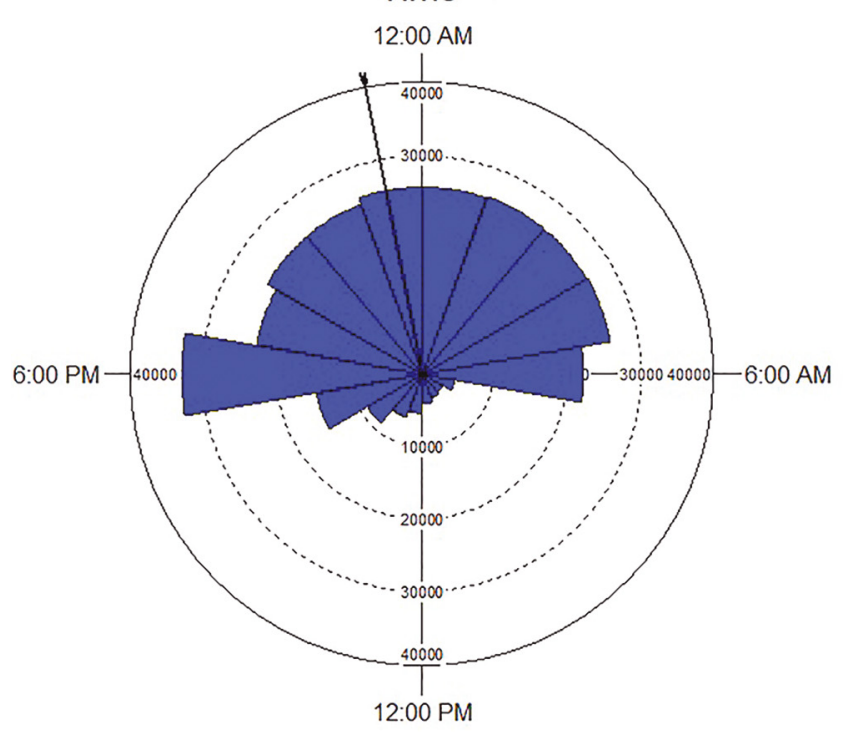

b

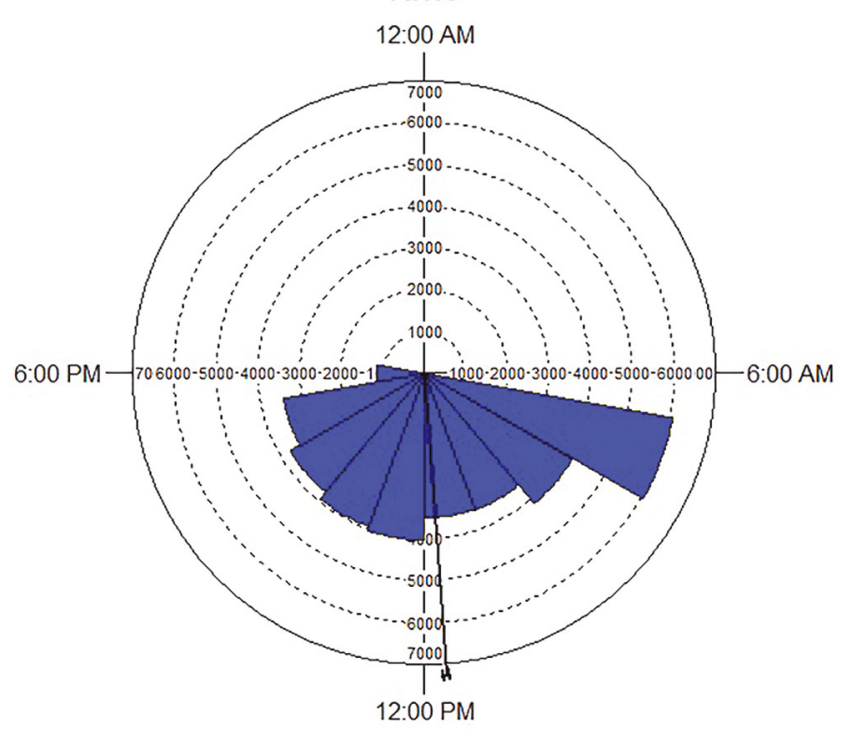

Fig. 9. Rose diagrams showing the proportion of detections recorded over time by receivers located at (a) a sleeping site and (b) a foraging site for 20 humphead wrasse Cheilinus undulatus acoustically tagged at a remote location in Seychelles 


\subsection{Population size structure}

The mean size of tagged humphead wrasse in Seychelles was $97.95 \mathrm{~cm}$, representing a population size structure larger than that observed in other parts of the species' range (mean size $=36 \mathrm{~cm}$ at the site in French Polynesia), where heavy fishing pressure has removed larger individuals (Lennox et al. 2019). Indeed, increased fishing pressure has been shown to reduce the size of targeted fish (Wilson et al. 2010, Barnett et al. 2017); therefore, the prevalence of large humphead wrasse at our study site suggests that targeted fishing pressure may be low. In Hong Kong and Indonesia, the size distribution of humphead wrasse confiscated from illegal fishing was skewed towards smaller individuals, with a modal length of $45 \mathrm{~cm}$ (range 20.8 to $129 \mathrm{~cm} \mathrm{TL;} \mathrm{Liu} \mathrm{\&}$ Sadovy de Mitcheson 2011). This distribution of size from the fishery indicates that larger individuals may be rare, although it should be noted that the live reef fish food trade has a preference for plate-sized fish.

In contrast, the size of humphead wrasse tagged by Weng et al. (2015) at a relatively unexploited site (Palmyra Atoll) had a mean size of $75 \mathrm{~cm}$ (range 28$109 \mathrm{~cm})$. Comparatively, fish tagged in this study were substantially larger (Table 1), suggesting that there may be regional size differences and that it is a healthy population with little exploitation and suitable habitat. There may be considerable variation in demography and other biological variables between sites, which may be mediated by physical environment, productivity, trophic and ecological interactions, or stochastic processes. However, based on the contrast in size structure between our study area and most other regions of the species' range, it appears that the study site in Seychelles is of very high value, and measures should be taken to ensure the protection of the fish and fish habitat in the area.

\subsection{Spatial and temporal extent of study}

The spatial scale used by tagged humphead wrasse was considerably smaller than the spatial scale monitored by the acoustic array, indicating that the spatial observation scale of this study was sufficient to capture the actual movements of tagged fish. In the event that the observation scale were too small, we would expect the fish to use most or all of the monitored area (thus allowing for the possibility that their home ranges were larger in scale than the acoustic array). The present study used an acoustic array of approximately $150 \mathrm{~km}$ length, whereas Weng et al.
(2015) monitored a region $20 \mathrm{~km}$ long, and Chateau \& Wantiez (2007) monitored a site approximately $0.8 \mathrm{~km}$ long. Activity space estimates by Weng et al. (2015) were about half the length of the monitored area, suggesting a sufficient scale. The individual tracked by Chateau \& Wantiez (2007) used all receivers in the array.

The total area occupied by tagged fish in the present study reached an asymptote prior to the end of the tracking period, suggesting that the period of time over which the tagged fish were monitored was sufficiently long to estimate their core home range size and the extent of their activity space. If the study period were too short, we would expect the area of the activity space to continue expanding up to the end of the monitoring period. However, as fish grow they may go through step changes in activity space corresponding with developmental/ontogenetic changes, such as sexual maturity or the change from female to male (Welsh et al. 2013). Furthermore, social processes such as changes in hierarchy may also influence activity space. The activity space estimates presented by Weng et al. (2015) reached an asymptote at 142 d with tracks averaging 373 d, suggesting a sufficient duration. The single individual studied by Chateau \& Wantiez (2007) had a track duration of $25 \mathrm{~d}$, which is much shorter than the time-to-asymptote in the present study or in that of Weng et al. (2015).

\subsection{Site fidelity}

The humphead wrasse tagged in this study appear to exhibit very high site fidelity. The core home range areas of all individuals occurred near their capture/ tagging locations, and since most captures occurred at sleeping locations, it is likely that each fish was returning to the same location each evening for shelter. The tagged individuals also showed high fidelity to their daytime foraging locations. While a variety of areas within the study area received high daytime usage, individuals tended to use the same area repeatedly. When daytime foraging locations were considered collectively, 4 groups of individuals were apparent. Each used a different foraging area during the day, despite the nocturnal shelter sites being common across groups. Additionally, the timing of repeated site use was predictable for all tagged fish with defined diel periodicity. Such predictable spatiotemporal habitat use emphasized the importance of the study site for the species and highlights its vulnerability to overexploitation. 
The availability of suitable sleeping sites appears to be an important habitat factor associated with high site fidelity for humphead wrasse. Shallow sloping reef (5-12 m) with undercut ledges and caves appeared to be particularly important for small to medium fish $(40-70 \mathrm{~cm})$, and some fish were found to shelter under large Porites coral colonies. It should be noted, however, that this latter behaviour was reported less frequently than for humphead wrasse observed at Palmyra Atoll (K. Weng pers. obs.).

In Seychelles, receivers located in close proximity to caves with a small entrance and large caverns on a shallow (5-12 m) reef slope were those that reported the highest number of detections, indicating the preference of humphead wrasse for such habitats. Fish occurred at these sleeping sites in groups of at least 11 individuals and often shared multi-compartmental caves. The small entrance to these caves is believed to be key here, given the discovery during the present study of a dead individual outside of a cave with a wide entrance. A shark bite was visible on the side of the large, adult fish, suggesting that sleeping caves with a small entrance are important for providing refuge from predators, and that the proximity of such caves is most likely an important consideration for fish when selecting habitats. Food availability and abundance are likely to be additional and important considerations for habitat choice by fish, but fall beyond the scope of this study.

\subsection{Home range}

In our Seychelles study site, all tagged fish had similar home range areas, whereas in Palmyra, male fish had much smaller home ranges than females. The authors speculated that males establish a territory and thus have a smaller home range than females, which are freer to travel in search of foraging opportunities. This may result in a decrease in space use over time as larger males may defend territories (Weng et al. 2015). However, since large (> 85 cm TL) presumably male fish in the present study appeared to have slightly larger activity spaces than females, it is possible that other site-specific factors such as distance between sleeping and foraging sites may be important determinants of activity space use. Indeed, ontogenetic shifts in home range of haremic species may be especially complex, and we suggest that further studies are required to investigate the drivers of juvenile, male and female activity space use (Welsh et al. 2013).
In order to facilitate the accurate comparison of home ranges between the humphead wrasse tagged in our study and other acoustically tagged marine species, we chose a standardized framework to calculate activity space metrics following Udyawer et al. (2018). When comparing home ranges using KUDs that apply different analytical methods, it makes comparison of the data inaccurate and thus, we can only accurately compare our results using bbKUDs to studies that apply the same approach (Udyawer et al. 2018). Compared to other marine species for which the extent of activity space (95\% bbKUD) has been calculated, humphead wrasse in our study exhibited relatively restricted activity spaces (95\% bbKUD; mean $=6.67 \mathrm{~km}^{2}$ ) much smaller than some sharks (grey reef shark Carcharhinus amblyrhynchos 95\% bbKUD; mean $=26.8 \mathrm{~km}^{2}$ ) and similar to small coastal fish species (yellowfin bream Acanthopagrus australis $95 \%$ bbKUD; mean $=7.9 \mathrm{~km}^{2}$ ) (Udyawer et al. 2018). Compared to other tropical marine fish species for which the total area of occupancy (MCP) was calculated, humphead wrasse tagged in our study exhibited a larger total area of occupancy (mean $\mathrm{MCP}=14.7 \mathrm{~km}^{2}$ ) to that of some groupers (3.6-3.9 $\left.\mathrm{km}^{2}\right)$ and a species of snapper $\left(6.2 \mathrm{~km}^{2}\right)$ (Farmer \& Ault 2014). However, the long term ( $>1$ yr) maximum dispersal distance exhibited by tagged wrasse in our study was substantially less $(16.16 \mathrm{~km})$ than another large fish (giant trevally Caranx ignobilis) tagged at the same study site, which undertook return movements of up to $90 \mathrm{~km}$ (SOSF 2018). Although the home range size of humphead wrasse may be influenced by site-specific factors, it appears that adults typically occupy a medium-sized activity space $\left(6.22 \mathrm{~km}^{2}\right)$ with limited dispersal. Further investigation will be required to determine how the home range size of humphead wrasse varies with habitat availability, particularly in locations where suitable sleeping and foraging sites are dispersed over a large area.

\subsection{Effective protection via spatial management}

This study highlighted the persistent ( $>1$ yr) restricted activity space use of tagged humphead wrasse at the study site and suggests that the postrecruitment population could be effectively protected via spatial management such as an MPA (Kramer \& Chapman 1999). Indeed, spatial management can be highly effective for fish species that exhibit limited spatiotemporal movements (Hilborn et al. 2004, Palumbi et al. 2004). Additionally, the 
spatial protection provided to the humphead wrasse encompasses the range of many other reef-associated species, such that the humphead wrasse serves as an umbrella species for conservation of an entire marine community (Weng et al. 2015). The results of this study showed that the previously proposed MPA boundary at the study site, situated $1 \mathrm{~km}$ from the respective Island and Atoll low tide mark, encompassed the core home range area for all tagged humphead wrasse and the extent of the activity space for all tagged fish, with the exception of 2 individuals. This provides evidence to suggest that a similar no-take MPA with a minimum buffer zone of $1 \mathrm{~km}$ from the local respective Island and Atoll low tide mark would be effective at protecting the studied population of humphead wrasse. It is important to note that although the core home range area for fish in Seychelles was consistent with that reported for the species at Palmyra Atoll (Weng et al. 2015), the tagged humphead wrasse population of our study may not have been representative of the entire population at the study site, as juveniles and female fish were underrepresented. While it is likely that the implementation of the proposed no-take MPA would also benefit these cohorts of the study population, future research efforts should endeavour to sample females and juveniles for completeness.

\subsection{Summary}

All tagged humphead wrasse exhibited high site fidelity and persistent and predictable activity space use at the study site in Seychelles. As such, they remain exceptionally vulnerable to over-exploitation. A spatial management plan using a no-take MPA should provide sufficient refuge for this currently unexploited population of Endangered humphead wrasse. It is recommended that the proposed no-take MPA boundary incorporates a buffer zone of at least $1 \mathrm{~km}$ around the full extent of activity space $(95 \%$ bbKUD) of all tagged fish to ensure protection for individuals that may be more wide ranging, such as smaller females, which were underrepresented in our study.

Acknowledgements. This study was supported by a grant from the Save Our Seas Foundation with additional support from the Virginia Institute of Marine Science to K.C.W. The views expressed herein are those of the authors and do not necessarily reflect the views of NOAA or any of its subdivisions. We thank the Seychelles Bureau of Standards and the Seychelles Ministry of Environment, Energy and Climate Change for their support.

\section{LITERATURE CITED}

Aumeeruddy R, Robinson J (2006) Closure of the live reef food fish fishery in Seychelles. SPC Live Reef Fish Inf Bull 16:3-9

* Barnett LAK, Branch TA, Ranasinghe RA, Essington TE (2017) Old-growth fishes become scarce under fishing. Curr Biol 27:2843-2848

Batschelet E (1981) Circular statistics in biology. Academic Press, New York, NY

Campbell HA, Watts ME, Dwyer RG, Franklin CE (2012) V-Track: software for analysing and visualising animal movement from acoustic telemetry detections. Mar Freshw Res 63:815-820

Chateau O, Wantiez L (2007) Site fidelity and activity patterns of a humphead wrasse, Cheilinus undulatus (Labridae), as determined by acoustic telemetry. Environ Biol Fishes 80:503-508

Choat JH, Davies CR, Ackerman JL, Mapstone BD (2006) Age structure and growth in a large teleost, Cheilinus undulatus, with a review of size distribution in labrid fishes. Mar Ecol Prog Ser 318:237-246

* Daly R, Stevens G, Daly CK (2018) Rapid biodiversity assessment records 16 new marine fish species for Seychelles, West Indian Ocean. Mar Biodivers Rec 11:6

*Dulvy NK, Sadovy Y, Reynolds JD (2003) Extinction vulnerability in marine populations. Fish Fish 4:25-64

Farmer NA, Ault JS (2014) Modeling coral reef fish home range movements in Dry Tortugas, Florida. ScientificWorldJournal 2014:629791

Friedlander AM, Obura D, Aumeeruddy R, Ballesteros E, Church J, Cebrian E, Sala E (2014) Coexistence of low coral cover and high fish biomass at Farquhar Atoll, Seychelles. PLOS ONE 9:e87359

Gillett R (2010) Monitoring and management of the humphead wrasse 'Cheilinus undulatus'. Fisheries and Aquaculture Circular No 1048. FAO, Rome

Hilborn R, Stokes K, Maguire JJ, Smith T and others (2004) When can marine reserves improve fisheries management? Ocean Coast Manag 47:197-205

Keating Daly CA, Daly R (2017) Preliminary report on the assessment of D'Arros and St Joseph as a refuge area for the endangered humphead wrasse, Cheilinus undulatus. Save Our Seas Foundation, Geneva

* Kramer DL, Chapman MR (1999) Implications of fish home range size and relocation for marine reserve function. Environ Biol Fishes 55:65-79

* Lea JSE, Humphries NE, von Brandis RG, Clarke CR, Sims DW (2016) Acoustic telemetry and network analysis reveal the space use of multiple reef predators and enhance marine protected area design. Proc R Soc B 283: 20160717

* Lennox RJ, Filous A, Cooke SJ, Danylchuk AJ (2019) Substantial impacts of subsistence fishing on the population status of an Endangered reef predator at a remote coral atoll. Endang Species Res 38:135-145

Lindenmayer D, Scheele B (2017) Do not publish. Science 356:800-801

Liu M, Sadovy de Mitcheson Y (2011) Forehead morphology of the humphead wrasse Cheilinus undulatus (Perciformes: Labridae) in relation to body size. Copeia 2011: 315-318

*McDermott GR, Meng KC, McDonald GG, Costello CJ (2019) The blue paradox: preemptive overfishing in marine reserves. Proc Natl Acad Sci USA 116:5319-5325 
R Core Team (2017) R: a language and environment for statistical computing. R Foundation for Statistical Computing, Vienna

Russell B (2004) Cheilinus undulatus. The IUCN Red List of Threatened Species 2004: e.T4592A11023949. http://dx. doi.org/10.2305/IUCN.UK.2004.RLTS.T4592A11023949. en (accessed 31 December 2019)

Russell GS, Levitin DJ (1995) An expanded table of probability values for Rao's spacing test. Commun Stat Simul Comput 24:879-888

Sadovy Y, Daves NK (2006) Development of fisheries management tools for trade in humphead wrasse, Cheilinus undulatus, in compliance with Article IV of CITES. Secretariat of the Convention on International Trade in Endangered Species of Wild Fauna and Flora, Geneva

Sadovy Y, Kulbicki M, Labrosse P, Letourneur Y, Lokani P, Donaldson TJ (2003) The humphead wrasse, Cheilinus undulatus: synopsis of a threatened and poorly known giant coral reef fish. Rev Fish Biol Fish 13:327-364

Sadovy Y, Punt AE, Cheung W, Vasconcellos M, Suharti S, Mapstone BD (2007) Stock assessment approach for the Napoleon fish Cheilinus undulatus, in Indonesia. Fisheries circular No. 1023. FAO, Rome

Sadovy de Mitcheson Y, Liu M, Suharti S (2010) Gonadal development in a giant threatened reef fish, the humphead wrasse Cheilinus undulatus, and its relationship to international trade. J Fish Biol 77:706-718

SOSF (Save Our Seas Foundation) (2018) Annual report.

Editorial responsibility: Austin Gallagher

Herndon, Virginia, USA https://issuu.com/saveourseas/docs/sosf-ar-2017 (accessed 5 January 2020)

Stoddart D (1984) Biogeography and ecology of the Seychelles. Kluwer, Boston, MA

Stoddart DR, Coe MJ, Fosberg FR (1979) D'Arros and St. Joseph, Amirante Islands. Atoll Res Bull 223:1-48

*Tulloch AIT, Auerbach N, Avery-Gomm S, Bayraktarov E and others (2018) A decision tree for assessing the risks and benefits of publishing biodiversity data. Nat Ecol Evol 2:1209-1217

Udyawer V, Dwyer RG, Hoenner X, Babcock RC and others (2018) A standardised framework for analysing animal detections from automated tracking arrays. Anim Biotelem 6:17

WWelsh JQ, Goatley CHR, Bellwood DR (2013) The ontogeny of home ranges: evidence from coral reef fishes. Proc $\mathrm{R}$ Soc B 280:20132066

*Weng KC, Pedersen MW, Del Raye GA, Caselle JE, Gray AE (2015) Umbrella species in marine systems: using the endangered humphead wrasse to conserve coral reefs. Endang Species Res 27:251-263

* Wilson SK, Fisher R, Pratchett MS, Graham NAJ and others (2010) Habitat degradation and fishing effects on the size structure of coral reef fish communities. Ecol Appl 20: $442-451$

Wu J, Sadovy de Mitcheson Y (2016) The trade in humphead wrasse into and through Hong Kong. SPC Live Reef Fish Inf Bull 21:24-27

Submitted: October 27, 2019; Accepted: March 24, 2020

Proofs received from author(s): May 1, 2020 